\title{
Last interglacial model-data mismatch of thermal maximum temperatures partially explained
}

\author{
P. Bakker ${ }^{1,2}$ and H. Renssen ${ }^{1}$ \\ ${ }^{1}$ Earth and Climate Cluster, Department of Earth Sciences, VU University Amsterdam, \\ 1081HV Amsterdam, the Netherlands \\ ${ }^{2}$ now at: College of Earth, Ocean and Atmospheric Sciences, Oregon State University, \\ Corvallis, Oregon, USA
}

Correspondence to: P. Bakker (p.bakker@ ceoas.oregonstate.edu)

Received: 3 February 2014 - Published in Clim. Past Discuss.: 25 February 2014

Revised: 24 June 2014 - Accepted: 24 July 2014 - Published: 29 August 2014

\begin{abstract}
The timing of the last interglacial (LIG) thermal maximum across the globe remains to be precisely assessed. Because of difficulties in establishing a common temporal framework between records from different palaeoclimatic archives retrieved from various places around the globe, it has not yet been possible to reconstruct spatio-temporal variations in the occurrence of the maximum warmth across the globe. Instead, snapshot reconstructions of warmest LIG conditions have been presented, which have an underlying assumption that maximum warmth occurred synchronously everywhere. Although known to be an oversimplification, the impact of this assumption on temperature estimates has yet to be assessed. We use the LIG temperature evolutions simulated by nine different climate models to investigate whether the assumption of synchronicity results in a sizeable overestimation of the LIG thermal maximum. We find that for annual temperatures, the overestimation is small, strongly modeldependent (global mean $0.4 \pm 0.3^{\circ} \mathrm{C}$ ) and cannot explain the recently published $0.67{ }^{\circ} \mathrm{C}$ difference between simulated and reconstructed annual mean temperatures during the LIG thermal maximum. However, if one takes into consideration that temperature proxies are possibly biased towards summer, the overestimation of the LIG thermal maximum based on warmest month temperatures is non-negligible with a global mean of $1.1 \pm 0.4^{\circ} \mathrm{C}$.
\end{abstract}

\section{Introduction}

The last interglacial period (LIG; 130-116 thousand years before present $[\mathrm{ka}]$ ) receives increasing attention because of the potential to constrain the impact of climate feedbacks such as increased melt rates of the major ice sheets in warm climates (Otto-Bliesner et al., 2006; Bakker et al., 2012, 2013; Stone et al., 2013) and to evaluate climate model performance for a warmer than present-day climate (Otto-Bliesner et al., 2006, 2013; Lunt et al., 2013; MassonDelmotte et al., 2013). To facilitate the model-data comparisons that are crucial in the evaluation of climate model performance, a number of compilations of reconstructed maximum LIG temperatures have been produced (e.g. Kaspar et al., 2005; CAPE Last Interglacial Project Members, 2006; Clark and Huybers, 2009; Turney and Jones, 2010; McKay et al., 2011), based on a variety of different temperature proxies, retrieved from ice, marine and terrestrial archives. However, because the LIG lies outside the time span covered by ${ }^{14} \mathrm{C}$ dating, absolute chronological uncertainties for this period can be up to $5000 \mathrm{yr}$ (Waelbroeck et al., 2008) and a common temporal framework can often not be established. This reality has led a number of authors (e.g. Kaspar et al., 2005; CAPE Last Interglacial Project Members, 2006; Clark and Huybers, 2009; Turney and Jones, 2010; McKay et al., 2011) to present a snapshot reconstruction of warmest LIG conditions, with the assumption that LIG maximum warmth occurred synchronously across large parts of the globe. A general conclusion from subsequent evaluations of LIG climate simulations is that models do not capture the degree 
of LIG warming suggested by proxy-based reconstructions, whether using annual, or warmest month temperatures (Lunt et al., 2013; Otto-Bliesner et al., 2013). For example, OttoBliesner et al. (2013) recently performed a comparison between a large number of continental and oceanic records and a LIG $(130 \mathrm{ka})$ time-slice simulation with the CCSM3 model. They find that for the proxy sites in the Northern Hemisphere $(\mathrm{NH})$ extratropical regions $\left(30-90^{\circ} \mathrm{N}\right)$, the reconstructed $1.71{ }^{\circ} \mathrm{C}$ annual mean temperature anomaly (with respect to pre-industrial; based on a combination of the compilations by Turney and Jones, 2010 and McKay et al., 2011 ) is considerably underestimated by the CCSM3 model $\left(0.76^{\circ} \mathrm{C}\right)$. This raises the question what causes this modeldata mismatch of the LIG thermal maximum.

One partial reason for the mismatch could be that the synchronicity assumption underlying the compilations of the LIG thermal maximum is a non-negligible simplification. Several transient modelling experiments and proxy-based temperature reconstructions for both the present interglacial (PIG) and the LIG have shown that there are large regional differences in the timing of interglacial maximum warmth, of the order of several thousands of years (Renssen et al., 2009, 2012; Bakker et al., 2012; Govin et al., 2012; Langebroek and Nisancioglu, 2014). These temporal differences result from latitudinal and seasonal differences in the evolution of the orbital forcing, from the thermal inertia of the oceans and from a variety of feedbacks in the climate system, such as the presence of remnant ice sheets from the preceding deglaciation, changes in sea-ice cover, vegetation, meridional overturning strength and monsoon dynamics. Moreover, these complexities in the orbital forcing and its interaction with climate feedbacks, cause seasonal differences in the timing of interglacial maximum warmth, e.g. the annual mean, summer or winter temperature maxima did not occur synchronously. As a consequence, a compilation of reconstructed LIG temperatures that combines LIG maximum temperatures from different regions, seasons and climatic archives yields temperature anomalies that are larger than the maximum temperatures that occurred at any given time during the LIG period.

We use the results of transient LIG climate simulations performed by nine different climate models to (i) assess the magnitude and robustness of the possible overestimation of the LIG thermal maximum caused by the assumption of synchronicity in space and time, and (ii) investigate the importance of the geographical region and the season over which the average is made. These results enable us to discuss the degree to which the overestimation of the LIG thermal maximum resulting from the synchronicity assumption can explain the differences found in model-data comparison studies.

\section{Method}

LIG temperature time series from a total of nine different climate models, ranging from earth system models of intermediate complexity (EMIC) to general circulation models (GCM), have previously been compared in Bakker et al. $(2013,2014)$. A thorough description of the simulations and climate models can be found there, while an overview is given in Table 1 . To investigate the possible overestimation of the LIG thermal maximum, we calculate the temperature anomalies in two different ways: (i) we calculate regionally averaged temperature anomaly time series and from that determine the warmest period (warmestsingle-period; WSP) and (ii) we assume synchronicity of the LIG thermal maximum in space and time by calculating for each individual model grid cell the largest LIG temperature anomaly and then combine these single-gridcell maxima into regional averages (compilation-warmestperiods; CWP). In other words, the result of the warmestsingle-period method can be regarded as a "real" estimate of the LIG thermal maximum, while the result from the compilation-warmest-periods is an analogue to the method used in proxy-based temperature compilations and yields an overestimated LIG thermal maximum that did not occur simultaneously within the LIG.

In broad agreement with the methods applied in the proxy-based compilations of CAPE Last Interglacial Project Members (2006), Turney and Jones (2010) and McKay et al. (2011), we limit the time frame of the two methods to 130-120 ka. Note that for the KCM and MPI-UW simulations, respectively, $126-120$ and $128-120 \mathrm{ka}$ is used, because they do not cover the full period. Sensitivity experiments are performed for $130-125 \mathrm{ka}$ to assess the importance of the definition of this time frame. To investigate the importance of the spatial domain for which the temperature anomalies are calculated, we look at the global scale, the Northern Hemisphere extratropics $\left(30-90^{\circ} \mathrm{N}\right)$, the tropics $\left(30^{\circ} \mathrm{S}-30^{\circ} \mathrm{N}\right)$ and the Southern Hemisphere $(\mathrm{SH})$ extratropics $\left(90-30^{\circ} \mathrm{S}\right)$. Annual mean proxy-based temperatures often include seasonal biases that are in turn dependent on the type of proxy and the region under consideration (Schneider et al., 2010; Leduc et al., 2010; Lohmann et al., 2013). To assess the impact on the results of a potential seasonal bias, we investigate anomalies of both annual mean temperatures and warmest month temperatures. Moreover, in the discussion we present maximum LIG temperatures following the compilation-warmest-periods method for the different seasons: March-April-May (MAM), June-July-August (JJA), September-October-November (SON) and December-January-February (DJF). This will allow us to discuss the possible impact of the synchronicity assumption for proxy-based records that are locally biased towards a certain season. The annual mean and warmest month calculations are performed for the multi-model mean (MMM) as well as for the individual models in order to eval- 
Table 1. Overview of transient LIG climate simulations. For each simulation included in this study the model name is given, the period for which the simulation is performed (in thousands of years before present), the included forcings (Orb $=$ orbital; acc $=10$-fold acceleration of orbital forcing; GHG = Greenhouse gas concentrations; Ice = remnants of glacial continental ice sheets in NH; FWF = freshwater fluxes related to remnant ice sheets), components that are included in addition to the atmosphere, ocean and sea ice, the model complexity (EMIC = earth system model of intermediate complexity; GCM = general circulation model), the resolution of the atmospheric and oceanic model components and references to publications in which more details on the LIG simulations and the model specifics can be found.

\begin{tabular}{|c|c|c|c|c|c|c|c|}
\hline Model name & Period & $\begin{array}{l}\text { Included } \\
\text { forcings }\end{array}$ & $\begin{array}{l}\text { Additional } \\
\text { components }\end{array}$ & $\begin{array}{l}\text { Model } \\
\text { complexity }\end{array}$ & $\begin{array}{l}\text { Resolution } \\
\text { atmospheric } \\
\text { component }\end{array}$ & $\begin{array}{l}\text { Resolution } \\
\text { oceanic } \\
\text { component }\end{array}$ & Reference \\
\hline Bern3D & $130-115$ & Orb, GHG,Ice, FWF & & EMIC & $\begin{array}{l}\text { between } 3.2^{\circ} \\
\text { and } 19.2^{\circ} \text { by } \\
10^{\circ} \text { and } 1 \text { vert. } \\
\text { layers }\end{array}$ & $\begin{array}{l}\text { between } 3.2^{\circ} \\
\text { and } 19.2^{\circ} \text { by } \\
10^{\circ} \text { and } 32 \text { vert. } \\
\text { layers }\end{array}$ & $\begin{array}{l}\text { Edwards and Marsh (2005) } \\
\text { Muller et al. (2006), } \\
\text { Ritz et al. (2011a, b), } \\
\text { Bakker et al. (2013) }\end{array}$ \\
\hline CCSM3 & $130-115$ & Orb $(\mathrm{acc})$ & & GCM & $\begin{array}{l}3.75^{\circ} \text { by } 3.75^{\circ} \\
(\mathrm{T} 31) \text { and } 26 \\
\text { vert. layers }\end{array}$ & $\begin{array}{l}3^{\circ} \text { by } 3^{\circ} \text { and } 25 \\
\text { vert. layers }\end{array}$ & $\begin{array}{l}\text { Collins et al. (2006), } \\
\text { Bakker et al. (2013) }\end{array}$ \\
\hline CLIMBER2 & $130-115$ & Orb, GHG & Vegetation & EMIC & $\begin{array}{l}10^{\circ} \text { by } 51^{\circ} \text { and } \\
1 \text { vert. layers }\end{array}$ & $\begin{array}{l}10^{\circ} \text { and } 11 \text { vert. } \\
\text { layers }\end{array}$ & $\begin{array}{l}\text { Petoukhov et al. (2000), } \\
\text { Bakker et al. (2013) }\end{array}$ \\
\hline COSMOS & $130-115$ & Orb (acc), GHG & & $\mathrm{GCM}$ & $\begin{array}{l}3.75^{\circ} \text { by } 3.75^{\circ} \\
(\mathrm{T} 31) \text { and } 31 \\
\text { vert. layers }\end{array}$ & $\begin{array}{l}3^{\circ} \text { by } 1.8^{\circ} \text { and } \\
42 \text { vert. layers }\end{array}$ & $\begin{array}{l}\text { Roeckner et al. (2003), } \\
\text { Marsland et al. (2003) }\end{array}$ \\
\hline CSIRO & $130-115$ & Orb (acc), GHG & & GCM & $\begin{array}{ll}5.625^{\circ} & \text { by } \\
3.18^{\circ} \text { and } & 18 \\
\text { vert. layers } & \end{array}$ & $\begin{array}{l}3.625^{\circ} \text { by } \\
3.18^{\circ} \text { and } 21 \\
\text { vert. layers }\end{array}$ & Phipps et al. $(2011,2012)$ \\
\hline FAMOUS & $130-115$ & Orb, GHG & & GCM & $\begin{array}{l}5^{\circ} \text { by } 7.5^{\circ} \text { and } \\
11 \text { vert. layers }\end{array}$ & $\begin{array}{l}2.5^{\circ} \text { by } 3.75^{\circ} \\
\text { and } 20 \text { vert. } \\
\text { layers }\end{array}$ & $\begin{array}{l}\text { Gordon et al. (2000), } \\
\text { Jones et al. (2005), } \\
\text { Smith and Gregory (2012), } \\
\text { Smith (2012), } \\
\text { Bakker et al. (2013) }\end{array}$ \\
\hline KCM & $126-115$ & Orb $(\operatorname{acc})$ & & GCM & $\begin{array}{l}3.75^{\circ} \text { by } 3.75^{\circ} \\
(\mathrm{T} 31) \text { and } 19 \\
\text { vert. layers }\end{array}$ & $\begin{array}{l}0.5^{\circ} \text { by } 1.3^{\circ} \\
\text { and } 31 \text { vert. } \\
\text { layers }\end{array}$ & $\begin{array}{l}\text { Park et al (2009), } \\
\text { Bakker et al. (2013) }\end{array}$ \\
\hline LOVECLIM & $130-115$ & Orb, GHG & & EMIC & $\begin{array}{l}5.6^{\circ} \text { by } 5.6^{\circ} \\
(\mathrm{T} 21) \text { and } 3 \\
\text { vert. layers }\end{array}$ & $\begin{array}{l}3^{\circ} \text { by } 3^{\circ} \text { and } 20 \\
\text { vert. layers }\end{array}$ & $\begin{array}{l}\text { Goosse et al. (2010), } \\
\text { Bakker et al. (2013) }\end{array}$ \\
\hline MPI-UW & $128-115$ & Orb, Prognostic $p \mathrm{CO}_{2}$ & Vegetation, Marinecarbon cycle,biogeochemistry & GCM & $\begin{array}{l}5.6^{\circ} \text { by } 5.6^{\circ} \\
(\mathrm{T} 21) \text { and } 19 \\
\text { vert. layers }\end{array}$ & $\begin{array}{l}4^{\circ} \text { by } 4^{\circ} \text { and } 22 \\
\text { vert. layers }\end{array}$ & $\begin{array}{l}\text { Schurgers et al. (2007), } \\
4 \text { Bakker et al. (2013) }\end{array}$ \\
\hline
\end{tabular}

uate the robustness of the results. All model output in this study has been regridded to a common $1^{\circ} \times 1^{\circ}$ resolution and the temperatures used are atmospheric $2 \mathrm{~m}$ temperature anomalies with respect to pre-industrial values. All time series are 50-year averages in order to filter out decadal and sub-decadal variability. Determining the temporal resolution of a proxy-based LIG temperature compilation is difficult because the included temperature records typically cover a large range of temporal resolutions. Therefore, we test the importance of the temporal resolution by performing sensitivity experiments with 250-year and 2000-year averaged temperatures in addition to 50-year averages.

\section{Results}

The calculations of the LIG thermal maximum based on the warmest-single-period and the compilation-warmest-periods methods, reveal large differences: between the individual models, between different geographical regions and between the annual mean and warmest month temperature anomalies. On a global scale the differences in the estimated LIG thermal maximum temperature anomaly between the two different methods are $0.4{ }^{\circ} \mathrm{C}$ for MMM annual temperatures, with an inter-model spread of $0.3^{\circ} \mathrm{C}(1 \sigma$; Fig. 1 and Ta- ble 2). For smaller geographical regions, the MMM differences in annual temperatures during the LIG thermal maximum are smaller in case of the tropics and SH extratropics $\left(0.2 \pm 0.2^{\circ} \mathrm{C}\right.$ and $0.3 \pm 0.3{ }^{\circ} \mathrm{C}$, respectively) and larger for the $\mathrm{NH}$ extratropics $\left(0.5 \pm 0.4^{\circ} \mathrm{C}\right)$ while the inter-model spread becomes larger in all three regions in comparison with the mean. The causes of the regional differences in the assessed overestimation of annual mean LIG maximum warmth will be discussed in the final part of the results section.

For warmest month temperature anomalies we find that the differences between the two methods used to calculated MMM LIG maximum temperature anomalies are much larger compared to the calculations based on annual temperatures. For warmest month temperatures the difference between the warmest-single-period and compilation-warmestperiods methods is globally $1.1 \pm 0.4^{\circ} \mathrm{C}$ and regionally $0.8 \pm 0.5^{\circ} \mathrm{C}$ ( $\mathrm{NH}$ extratropics), $0.8 \pm 0.2^{\circ} \mathrm{C}$ (tropics) and $0.6 \pm 0.3^{\circ} \mathrm{C}$ (SH extratropics; Fig. 1 and Table 2). For a description of the spatial differences in the timing of the warmest part of the LIG according to the transient climate simulations, we refer to Bakker et al. (2013). It is interesting to note that the simulated geographical pattern in the warmest month of the year during the LIG thermal maximum, does 
Table 2. MMM overestimation of LIG maximum warmth. Simulated MMM LIG temperature anomalies $\left({ }^{\circ} \mathrm{C}\right)$ for the single-warmest-period and for compilation-warmest-periods. Values are given for annual mean temperatures and for temperatures of the warmest month as well as for four different geographical regions: global, $\mathrm{NH}$ extratropical $\left(30-90^{\circ} \mathrm{N}\right)$, tropics $\left(30^{\circ} \mathrm{S}-30^{\circ} \mathrm{N}\right)$ and $\mathrm{SH}$ extratropical $\left(90-30^{\circ} \mathrm{S}\right)$. The last column gives the difference between the two methods and the inter-model spread $(1 \sigma)$. All values are anomalies compared to simulated pre-industrial temperatures. The warmest-single-period is the largest 50-year temperature anomaly found in the regionally averaged temperature evolution. On the other hand, the compilation-warmest-periods follows from a regional average over the highest 50-year temperature anomalies found in each individual grid cell within that region. Calculations are performed for the 130-120 ka period of the LIG.

\begin{tabular}{llccc}
\hline $\begin{array}{l}\text { Geographic } \\
\text { region }\end{array}$ & & $\begin{array}{c}\text { Warmest-single- } \\
\text { period }\left({ }^{\circ} \mathrm{C}\right)\end{array}$ & $\begin{array}{c}\text { Compilation-warmest- } \\
\text { period }\left({ }^{\circ} \mathrm{C}\right)\end{array}$ & $\begin{array}{c}\text { Difference } \\
\pm 1 \sigma\left({ }^{\circ} \mathrm{C}\right)\end{array}$ \\
\hline Global & Annual & 0.4 & 0.8 & $0.4 \pm 0.3$ \\
& Warmest month & 1.3 & 2.4 & $1.1 \pm 0.4$ \\
NH extratropics & Annual & 0.9 & 1.4 & $0.5 \pm 0.4$ \\
& Warmest month & 3.8 & 4.6 & $0.8 \pm 0.5$ \\
Tropics & Annual & 0.3 & 0.5 & $0.2 \pm 0.1$ \\
\multirow{3}{*}{ SH extratropics } & Warmest month & 1.2 & 2.0 & $0.8 \pm 0.2$ \\
& Annual & 0.5 & 0.9 & $0.3 \pm 0.3$ \\
& Warmest month & 0.4 & 1.0 & $0.6 \pm 0.3$ \\
\hline
\end{tabular}

not simply follow the month of highest insolation. We find that over the NH extratropical continents the warmest month is generally June, for the NH extratropical oceans it is August and for the SH extratropical oceans February (Fig. 3). In the low latitudes the land-sea differences are also apparent, but on top of that, monsoon dynamics and other local processes appear to play an important role in shaping the seasonal temperature evolution.

The quantification of the potential overestimation of LIG maximum warmth reveals the importance of the spatial domain over which the calculations are performed. The relatively large differences found for the globally averaged LIG thermal maximum based on warmest month temperatures are a direct consequence of the large contrast in the evolution of orbitally forced summer insolation between the high latitudes of the NH and the SH (Bakker et al., 2013). The annual global warmest-single-period is characterised by a MMM warming of $\sim 1{ }^{\circ} \mathrm{C}$ over the mid-to-high latitudes of the $\mathrm{NH}$ compared to simulated pre-industrial values, a $\sim 0.5^{\circ} \mathrm{C}$ warming over the SH mid-latitude continents and over Antarctica (Fig. 4). In contrast, the African and Indian monsoon regions show $\mathrm{a} \sim 1^{\circ} \mathrm{C}$ cooling compared to pre-industrial. If this is compared to the annual compilation-warmest-periods, we will not find a cooling in the monsoon regions and the warming in the mid-to-high latitudes of both hemispheres is on average $\sim 0.5^{\circ} \mathrm{C}$ larger than the single-warmest-period temperature anomalies. Over the tropical oceans the differences between both methods are small. For warmest month temperatures we find a different picture. Because of the contrasting LIG evolution of summer insolation for the $\mathrm{NH}$ and the $\mathrm{SH}$, the warmest month global warmest-single-period is characterised by a warming of $\sim 5^{\circ} \mathrm{C}$ over the $\mathrm{NH}$ continents and $\sim 2{ }^{\circ} \mathrm{C}$ over the $\mathrm{NH}$ oceans while for the same period simulated SH warmest month temperatures are $\sim 0.5^{\circ} \mathrm{C}$ below pre-industrial values. In contrast, the compilation-warmest- periods temperatures in the $\mathrm{SH}$ show a $0.5^{\circ} \mathrm{C}$ warming for warmest month temperatures, especially over the continents. $\mathrm{NH}$ warming in the compilation-warmest-periods is also larger than in the global warmest-single-period.

Some aspects of the investigation into the importance of the synchronicity assumption appear strongly model dependent. This is especially so for the calculated overestimation of LIG maximum warmth for the NH extratropics, both for annual and warmest month temperatures (Figs. 1 and 2). This is likely related to important feedbacks that are largely restricted to this region, like the strength of the meridional overturning, Arctic sea-ice evolution and the remnants of $\mathrm{NH}$ continental ice sheets from the preceding deglaciation. Note that the latter feedback is only included in the Bern3D simulation. Bakker et al. (2013) showed for a seven-member subset of the nine simulations presented here that sea-ice feedbacks in the Arctic are strongly model dependent causing large differences between the models in the simulated climate evolution at these high $\mathrm{NH}$ latitudes. The impact of changes in the meridional overturning will be discussed at the end of this paragraph. Another inter-model difference that is found especially for annual mean temperatures, is the contrast between high- and low-resolution models (Fig. 1). The calculated overestimation of LIG maximum warmth is strikingly smaller in Bern3D, CLIMBER2, FAMOUS and LOVECLIM, i.e. the models with the lowest spatial resolution in the model inter-comparison. This difference has two potential causes. First, models with reduced resolution and complexity are known to have generally less internal variability compared to GCMs (Gregory et al., 2005; Bakker et al., 2013), resulting in a climate evolution that is more coherent in space and thus a more spatially homogenous temperature maximum. A second possible explanation relates to the fact that the included EMICs all reveal relatively large, albeit strongly different in magnitude and sign, 


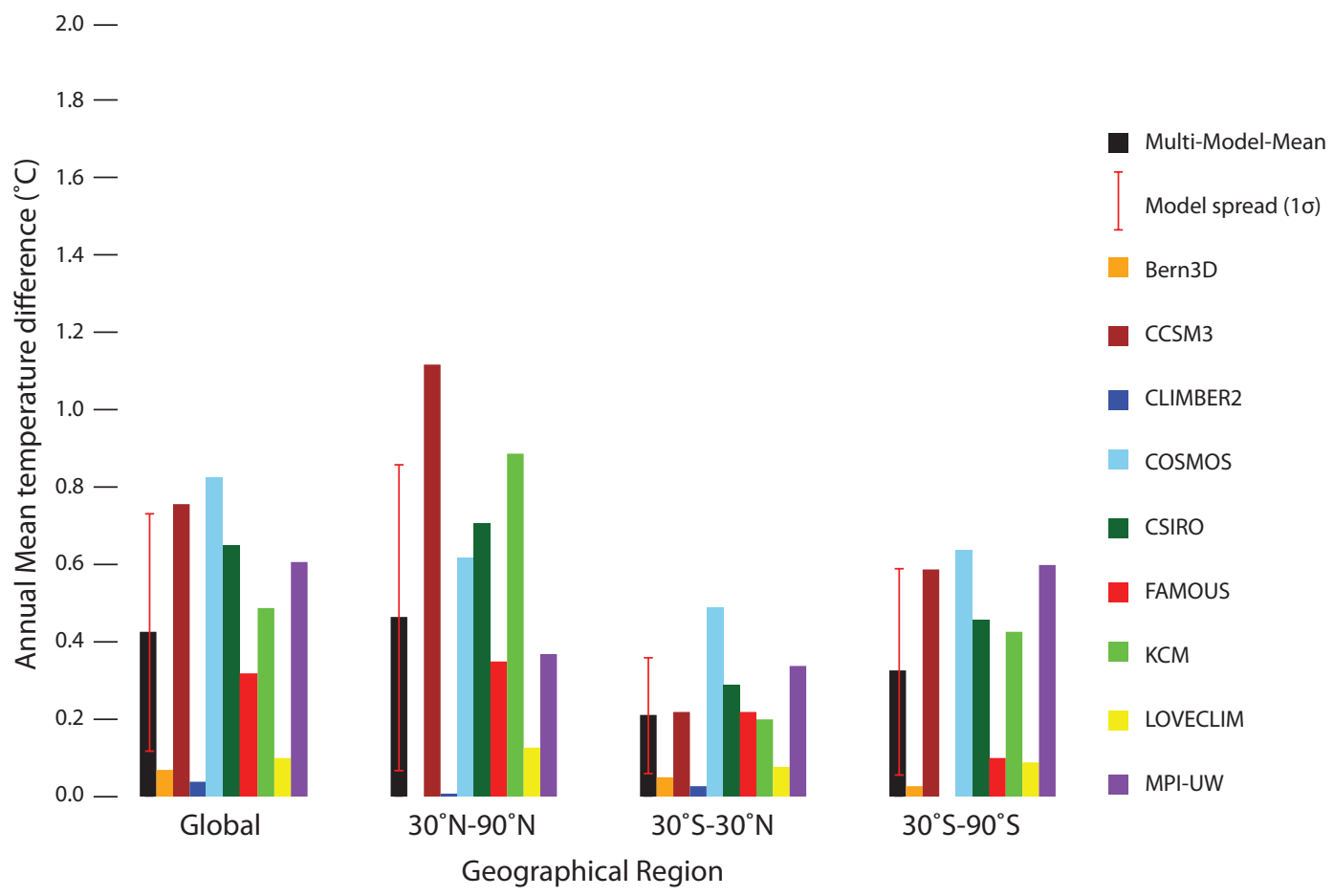

Figure 1. Overestimation of LIG maximum warmth taking into account simulated annual mean temperatures. Differences between the compilation-warmest-periods and the warmest-single-period methods to calculate the simulated LIG thermal maximum annual mean temperature anomalies $\left({ }^{\circ} \mathrm{C}\right)$. Results are given for four different geographical regions and for MMM temperature differences (black with $1 \sigma$ inter-model spread in red) and for the nine individual model runs.

changes in the meridional overturning circulation (Bakker et al., 2013); changes that arise as internal climate variability, with the exception of the Bern3D simulation that includes prescribed meltwater fluxes from remnants of $\mathrm{NH}$ continental ice sheets from the preceding deglaciation. Changes in the meridional overturning circulation have a large impact on surface temperatures and can therewith act to strongly synchronise simulated LIG maximum temperatures over extensive parts of the globe, thus decreasing the difference between the warmest-single-period and compilation-warmestperiods temperatures.

\section{Discussion}

We have shown that in climate models the synchronicity assumption potentially results in a sizeable overestimation of the LIG thermal maximum. However, to assess the possible overestimation of the LIG thermal maximum, two arbitrary choices have been made. First, we selected the 130-120 ka period to represent the LIG in this analysis, and second, we applied a 50-year average to the simulated temperature time series. To test the robustness of the results with respect to these two choices, we performed two additional sets of calculations in which we (1) used a $130-125 \mathrm{ka}$ period instead of 130-120 ka and (2) used 250-year and 2000-year averaged temperature time series instead of 50-year averages. We find that the resulting MMM overestimation of the LIG thermal maximum becomes smaller if the LIG period is decreased to 130-125 ka (annual mean global difference of $0.3 \pm 0.2^{\circ} \mathrm{C}$ instead of $0.4 \pm 0.3{ }^{\circ} \mathrm{C}$ ), in case the time averaging is increased to 250-year (annual mean global difference of $0.3 \pm 0.2{ }^{\circ} \mathrm{C}$ instead of $0.4 \pm 0.3{ }^{\circ} \mathrm{C}$ ) and even more so if the time averaging is increased to 2000 -year (annual mean global difference of $0.1 \pm 0.1^{\circ} \mathrm{C}$ instead of $0.4 \pm 0.3^{\circ} \mathrm{C}$; see Table 3 for more details and regional differences). The explanation is that decreasing the length of the analysis period, limits the insolation differences between the two hemispheres. Furthermore, larger temporal averages smooth out an increasing part of the spatial differences related to internal variability, again decreasing spatio-temporal differences in the LIG temperature maximum. Nonetheless, the main features described above appear robust.

In the results discussed so far, we focused on annual mean and warmest month temperatures. However, seasonal biases in proxy-based temperature reconstructions from a specific region can also be towards other seasons, for instance to average summer temperatures or towards the spring/autumn bloom periods (Schneider et al., 2010; Leduc et al., 2010; Lohmann et al., 2013). To see how such a seasonal bias would impact the results, we compare compilation-warmestperiods for all four seasons with the annual mean and 
Table 3. Robustness of MMM overestimation of LIG maximum warmth. Calculated MMM overestimation of LIG maximum warmth (mean $\pm 1 \sigma ;{ }^{\circ} \mathrm{C}$ ) and the dependence of the results on the two main choices: time frame of the LIG period over which the calculations are performed (130-120 ka in columns 3, 4 and 5; 130-125 ka in column 6) and the temporal resolution of the simulated temperature time series (50-year averages in columns 3 and 6; 250-year averages in column 4; 2000-year averages in column 5). Values are given for annual mean temperatures and for temperatures of the warmest month as well as for four different geographical regions: global, $\mathrm{NH}$ extratropics $\left(30-90^{\circ} \mathrm{N}\right)$, tropics $\left(30^{\circ} \mathrm{S}-30^{\circ} \mathrm{N}\right)$ and $\mathrm{SH}$ extratropical $\left(90-30^{\circ} \mathrm{S}\right)$.

\begin{tabular}{llllll}
\hline $\begin{array}{l}\text { Geographic } \\
\text { region }\end{array}$ & 130-120 ka & $\begin{array}{l}\text { 130-120 ka } \\
\text { 50-year averages }\end{array}$ & $\begin{array}{l}\text { 130-120 ka } \\
\text { 250-year averages }\end{array}$ & $\begin{array}{l}\text { 130-125 ka } \\
\text { 2000-year averages }\end{array}$ & 50-year averages \\
\hline Global & Annual & $0.4 \pm 0.3$ & $0.2 \pm 0.2$ & $0.1 \pm 0.1$ & $0.3 \pm 0.2$ \\
& Warmest month & $1.1 \pm 0.4$ & $0.7 \pm 0.2$ & $0.5 \pm 0.1$ & $0.7 \pm 0.3$ \\
NH extratropics & Annual & $0.5 \pm 0.4$ & $0.2 \pm 0.2$ & $0.1 \pm 0.1$ & $0.3 \pm 0.3$ \\
& Warmest month & $0.8 \pm 0.5$ & $0.3 \pm 0.2$ & $0.1 \pm 0.1$ & $0.7 \pm 0.5$ \\
Tropics & Annual & $0.2 \pm 0.1$ & $0.1 \pm 0.1$ & $0.1 \pm 0.1$ & $0.1 \pm 0.1$ \\
& Warmest month & $0.8 \pm 0.2$ & $0.5 \pm 0.1$ & $0.4 \pm 0.1$ & $0.5 \pm 0.3$ \\
SH extratropics & Annual & $0.3 \pm 0.3$ & $0.2 \pm 0.2$ & $0.1 \pm 0.1$ & $0.3 \pm 0.3$ \\
& Warmest month & $0.6 \pm 0.3$ & $0.3 \pm 0.2$ & $0.1 \pm 0.1$ & $0.5 \pm 0.3$ \\
\hline
\end{tabular}

warmest month compilation-warmest-periods (Fig. 5). Note that calculating the single-warmest-period over a large spatial domain, for instance a global average, for a specific set of months, for instance MAM, is meaningless because such an average would combine temperatures from largely different seasons (see also Fig. 3). We find that the compilationwarmest-periods temperature anomalies in the $\mathrm{NH}$ extratropics are largest in JJA while they are largest in SON over the SH extratropical continents and part of the Southern Ocean. Interpreting the seasonal temperature anomalies in terms of the potential overestimation of the LIG thermal maximum is difficult, because it is the temperature anomaly in combination with spatial differences in the occurrence of the temperature anomalies within the LIG that determine the size of the overestimation. Notwithstanding this limitation, the maximum seasonal temperature anomalies that occurred during the 130-120 ka period as found in the MMM provide a good reference for future studies into the seasonality aspects of different temperature proxies.

To assess if the calculated overestimation of the LIG thermal maximum can explain part of the reported modeldata mismatch (Lunt et al., 2013; Otto-Bliesner et al., 2006, 2013), we compare our results with the findings of OttoBliesner et al. (2013). They performed a number of sensitivity experiments with the CCSM3 climate model, with for instance different orbital parameters, and compared their results with proxy-based compilations of Turney and Jones (2010) and McKay et al. (2011), including both continental and oceanic temperature reconstructions. Otto-Bliesner et al. (2013) show that the smallest LIG thermal maximum modeldata differences are found in a model simulation forced with 130 ka forcings (orbital parameters and greenhouse-gas concentrations). Moreover, the model-data difference is found to be smaller if the comparison is performed at the proxy locations instead of taking the model average over all grid cells within the geographical domain under consideration (see Otto-Bliesner et al., 2013, for thorough model and scenario description). Nonetheless, a global mean model-data temperature difference of $0.67^{\circ} \mathrm{C}$ is found (anomalies of 0.98 and $0.31^{\circ} \mathrm{C}$ with respect to preindustrial values in the reconstructions and simulations, respectively). The MMM overestimation of LIG thermal maximum annual mean temperatures presented here $\left(0.4 \pm 0.3^{\circ} \mathrm{C}\right)$ can only provide a partial explanation of this model-data difference (Fig. 6). We do note that for a number of individual models an annual mean global overestimation of over $0.6^{\circ} \mathrm{C}$ is found. If the $0.98^{\circ} \mathrm{C}$ global temperature increase during the LIG thermal maximum (Otto-Bliesner et al., 2013) would be biased towards the warmest month, the calculated global $1.1 \pm 0.4^{\circ} \mathrm{C}$ overestimation resulting from the synchronicity assumption could potentially fully explain the model-data difference of $0.67^{\circ} \mathrm{C}$ (Fig. 6). Also for specific geographical regions like the tropics, we find that the model-data difference can potentially be explained by the calculated overestimation for the warmest month temperatures (simulated $0.8 \pm 0.2^{\circ} \mathrm{C}$ with respect to a $0.50^{\circ} \mathrm{C}$ model-data difference). In the $\mathrm{NH}$ extratropics the simulated MMM of $0.8 \pm 0.5^{\circ} \mathrm{C}$ is comparable to the $0.67^{\circ} \mathrm{C}$ model-data difference; however, the intermodel spread is large with values ranging from $\sim 0.05$ up to $\sim 1.5^{\circ} \mathrm{C}$. For the $\mathrm{SH}$ extratropical regions, the calculated MMM overestimation of $0.6 \pm 0.3{ }^{\circ} \mathrm{C}$ is small compared to the reported model-data difference of $1.40^{\circ} \mathrm{C}$ and not a single model simulation yields a value of over $1{ }^{\circ} \mathrm{C}$. Interestingly, we find that the calculated overestimation of LIG maximum warmth in the CCSM3 model run included in our study, the same model as used by Otto-Bliesner et al. (2013) for their model-data comparison, is always larger than the MMM. A comparison between the CCSM3 LIG equilibrium simulations presented by Otto-Bliesner et al. (2013) and the transient CCSM3 simulation presented here is far from straightforward and not easily interpreted. The difference between the equilibrium experiments presented by 


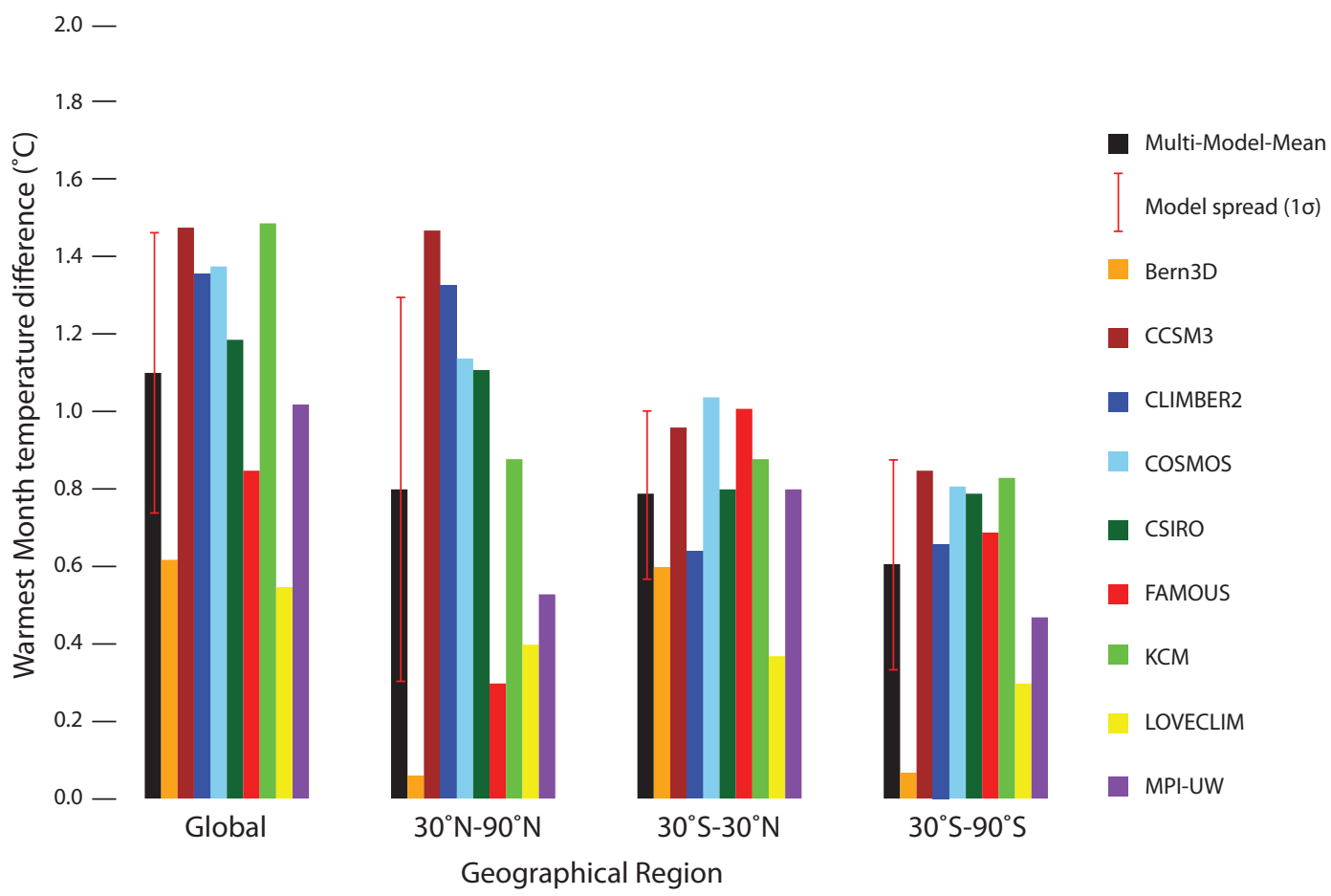

Figure 2. Overestimation of LIG maximum warmth taking into account simulated warmest month temperatures.Differences between the compilation-warmest-periods and the warmest-single-period methods to calculate the simulated LIG thermal maximum warmest month temperature anomalies $\left({ }^{\circ} \mathrm{C}\right)$. Results are given for four different geographical regions and for MMM temperature differences (black with $1 \sigma$ inter-model spread in red) and for the nine individual model runs.

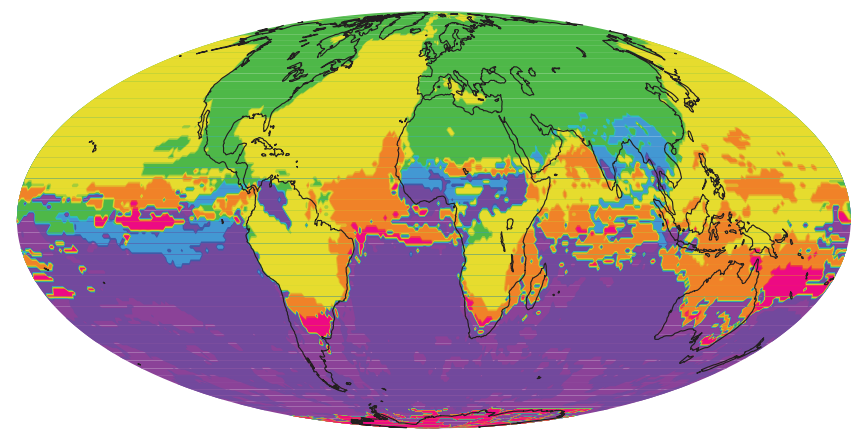

Jan Feb Mar Apr May Jun Jul Aug Sep Oct Nov Dec

Figure 3. Multi-model mean months of LIG maximum warmth. Month during which 50-year averaged LIG maximum warmth is found. Median of the nine different models is taken as the multimodel mean and for the calculations of LIG maximum warmth we applied the compilation-warmest-periods method, e.g. maximum LIG temperatures per individual grid cell.

Otto-Bliesner et al. (2013) and the transient climate simulations analysed here, can potentially impact the comparison between both studies. Most notably because it is unlikely that in reality the climate was in equilibrium with maximum LIG $\mathrm{NH}$ summer insolation and greenhouse-gas concentrations as implied by the set-up of Otto-Bliesner et al. (2013). However, because this maximum LIG radiative forcing was only applied for $1 \mathrm{ky}$, we deem it unlikely to be of large importance for the presented comparison between both studies.

The assessment of the overestimation of LIG maximum warmth presented here is imperfect. The lack of a statistical analysis of the significance of the calculated overestimation compared to the literature-based model-data mismatch is a profound limitation to the current study. However, reliable uncertainty estimates for the reconstructed LIG temperature compilations are not available. Another limitation of the included proxy-based reconstructions in the study by Otto-Bliesner et al. (2013) is the non-uniform spatial distribution of the proxy-records, a feature that will impact the data since the spatial differences in maximum warmth described in the present study are large. However, quantifying the impact of the limited spatial data coverage on the modeldata mismatch is far from straightforward. There are also a number of limitations to the presented climate model simulations. The models included in this study are all known to have specific biases for the present-day climate; notwithstanding, we deem the impact of these biases small since we only use LIG anomalies with respect to the pre-industrial climate. Another limitation of the included climate model simulations is the difficulty they have to mimic the reconstructed near synchronicity between $\mathrm{NH}$ and $\mathrm{SH}$ high-latitude warming during 

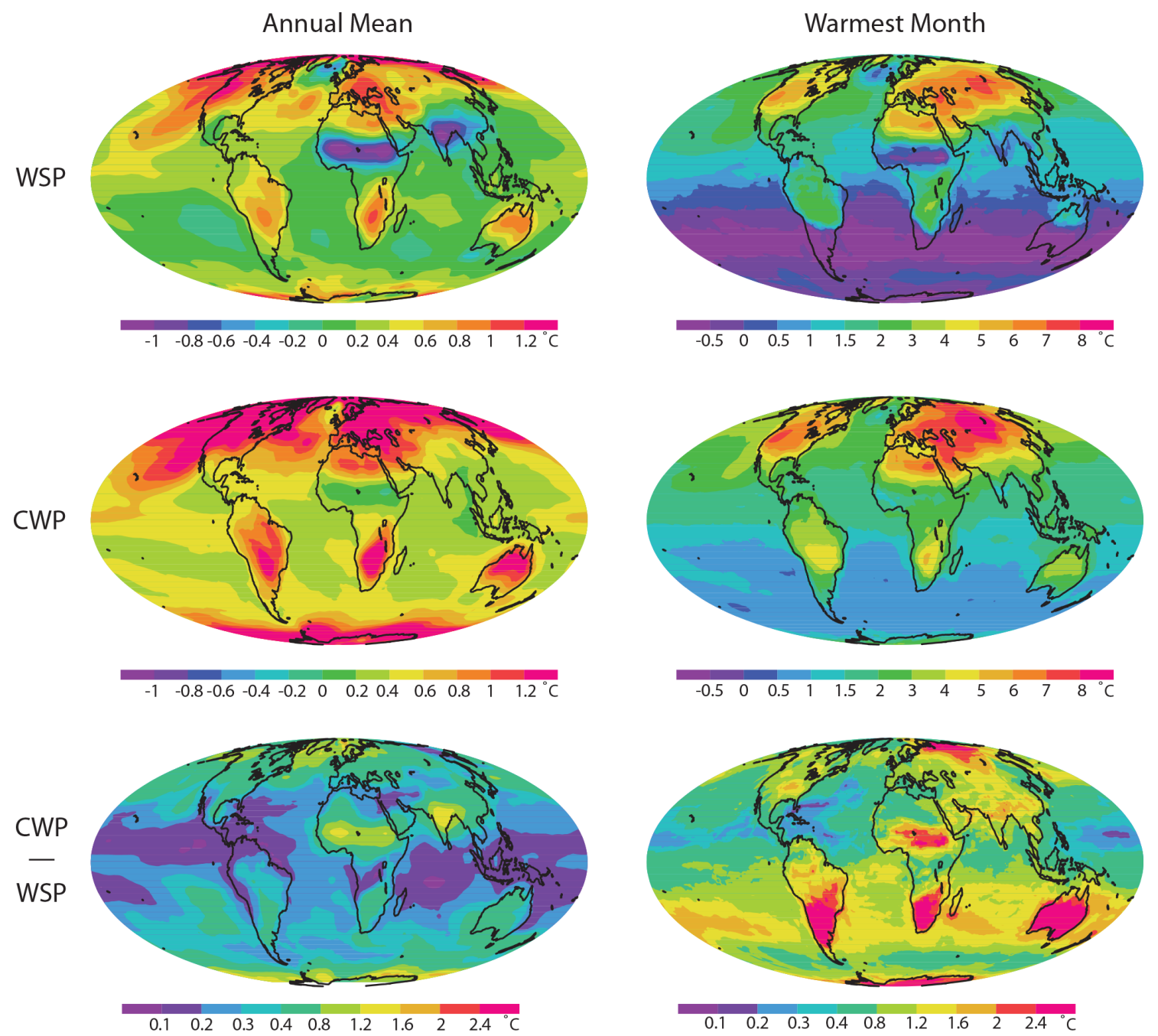

Figure 4. Spatial differences in quantified overestimation of LIG maximum temperatures for annual mean and warmest month temperatures. Map of MMM LIG maximum temperature anomalies $\left({ }^{\circ} \mathrm{C}\right.$ ) compared to pre-industrial for the warmest-single-period (WSP, top row), the compilation-warmest-periods (CWP, middle row) and the difference between the two methods (CWP-WSP, bottom row). Maps are presented for both simulated annual mean and warmest month temperatures. Warmest-single-period results shown here are based on the globally averaged single-warmest-period. Note the differences and the non-linearity in the colour scales.

the early LIG (Bakker et al., 2013, 2014), with most models showing SH maximum LIG temperatures $<120 \mathrm{ka}$ and NH maximum LIG temperatures $>125 \mathrm{ka}$. Furthermore, the LIG simulations are not all forced with identical climate forcings. Most notably, the CCSM3 and KCM simulations lack transient greenhouse-gas concentration changes, the Bern3D simulation includes remnants of glacial ice sheets and related meltwater fluxes, the CLIMBER2 and MPI-UW simulations include dynamic calculations of vegetation feedbacks while the other models do not and finally the CCSM3, COSMOS, CSIRO and KCM include an accelerated orbital forcing with a potential impact on the simulated internal variability of the climate. The lack of remnant ice sheets during the early LIG in the simulations (except the Bern3D simulation) potentially impacts the heterogeneity of the thermal maximum (Renssen et al., 2009). Even though Kopp et al. (2009) have shown that already by $129 \mathrm{ka}$ sea level was close to its present-day value, the different phasing for the PIG and the LIG between the NH continental ice sheet regression and NH peak summer insolation could potentially impact the validity of the maximum warmth heterogeneity assumption as postulated for the PIG. A final important limitation of our study is linked to the fact that it is obviously not ideal to use the tools that require evaluation, to evaluate the reference data set. Notwithstanding, until chronologies for the LIG become better constrained, climate models are the only tool with which an assessment of the possible overestimation of the LIG thermal maximum can be made. We argue that the outcomes presented in this study are helpful in understanding part of the large differences between reconstructed and simulated LIG temperatures. 

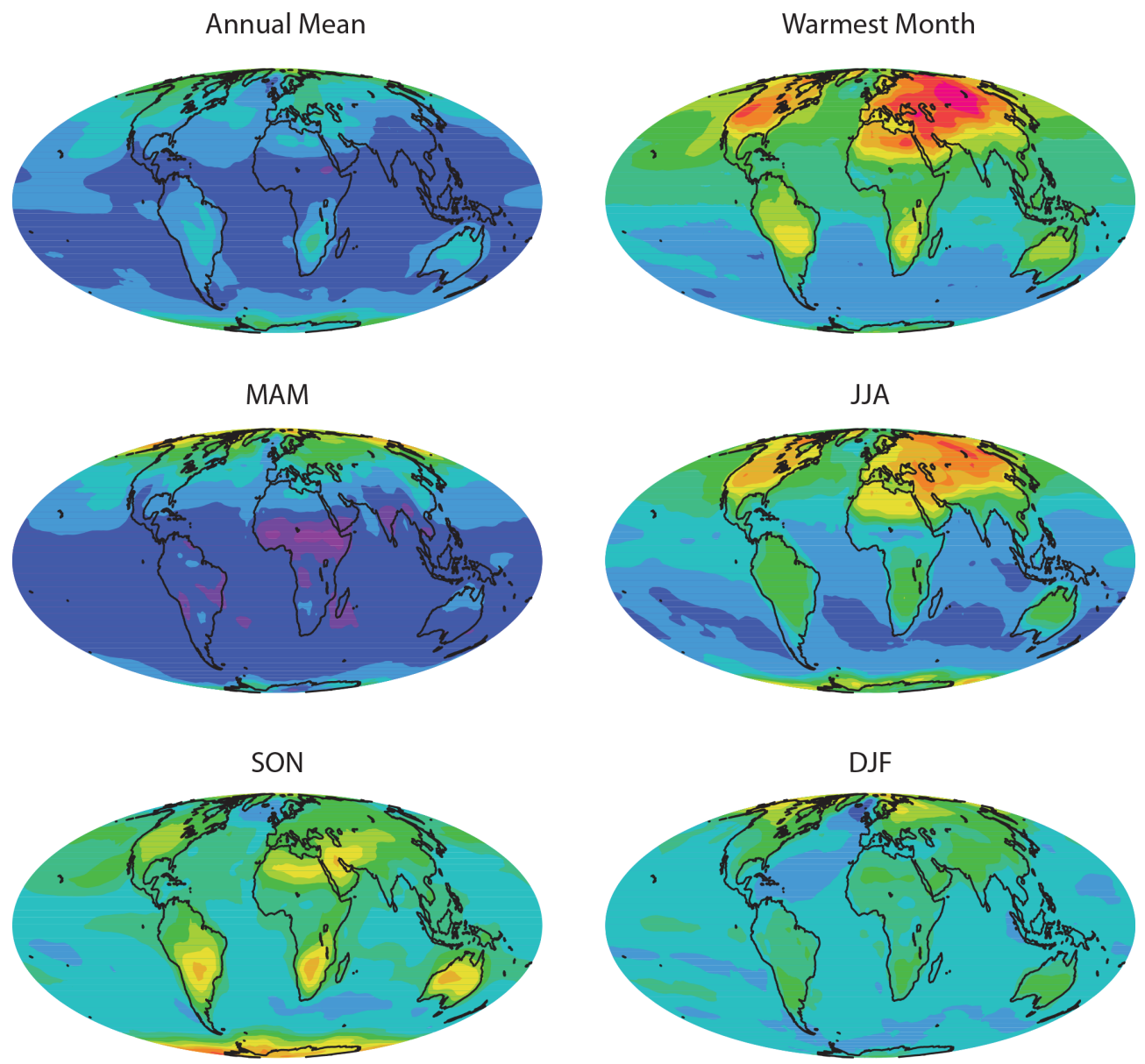

$\begin{array}{lllllllllllll}-0.5 & 0 & 0.5 & 1 & 1.5 & 2 & 3 & 4 & 5 & 6 & 7 & 8 & { }^{\circ} \mathrm{C}\end{array}$

Figure 5. Spatial differences in LIG maximum temperatures $\left({ }^{\circ} \mathrm{C}\right)$ compared to pre-industrial for DJF, MAM, JJA and SON temperatures following the compilation-warmest-periods (CWP) methodology.

\section{Conclusions}

With transient simulations covering the LIG period by nine different climate models, we investigate whether the assumption of synchronicity in space and time of the LIG thermal maximum that has to be made in compiling reconstructed LIG temperatures, results in a sizable overestimation of the LIG thermal maximum. For annual mean temperatures, the calculated overestimation is small, strongly modeldependent (global $\mathrm{MMM}$ of $0.4{ }^{\circ} \mathrm{C}$ with $\mathrm{a} \pm 0.3{ }^{\circ} \mathrm{C}$ intermodel spread) and cannot explain the $0.67^{\circ} \mathrm{C}$ model-data difference described by Otto-Bliesner et al. (2013). However, if reconstructed LIG temperatures would prove to be partly biased towards the warm season, the calculated global and tropical overestimation of the LIG thermal maximum based on simulated warmest month temperatures (global MMM $1.1 \pm 0.4{ }^{\circ} \mathrm{C}$; tropics MMM $0.8 \pm 0.2^{\circ} \mathrm{C}$ ) can potentially fully explain the global and tropical model-data differences described by Otto-Bliesner et al. (2013), $0.67^{\circ} \mathrm{C}$ and
$0.33{ }^{\circ} \mathrm{C}$, respectively. For the extratropics, the overestimation can explain only part of the model-data differences, indicating that additional explanations are required. Notwithstanding that the exact magnitude of the calculated overestimation is depending on applied methodology and climate models, our findings suggest that global compilations of reconstructed the LIG thermal maximum overestimate the warming, therewith providing a partial explanation of the LIG thermal maximum model-data mismatch found in previous studies. Currently, new methodologies are being developed to provide a better age control for LIG temperature reconstructions, potentially decreasing the importance of the overestimation discussed in this manuscript. Another aspect that could greatly improve current model-data comparisons of the LIG temperature evolution is a better understanding of the reconstructed changes in the SH mid-to-high latitude and its representation in climate simulations. 


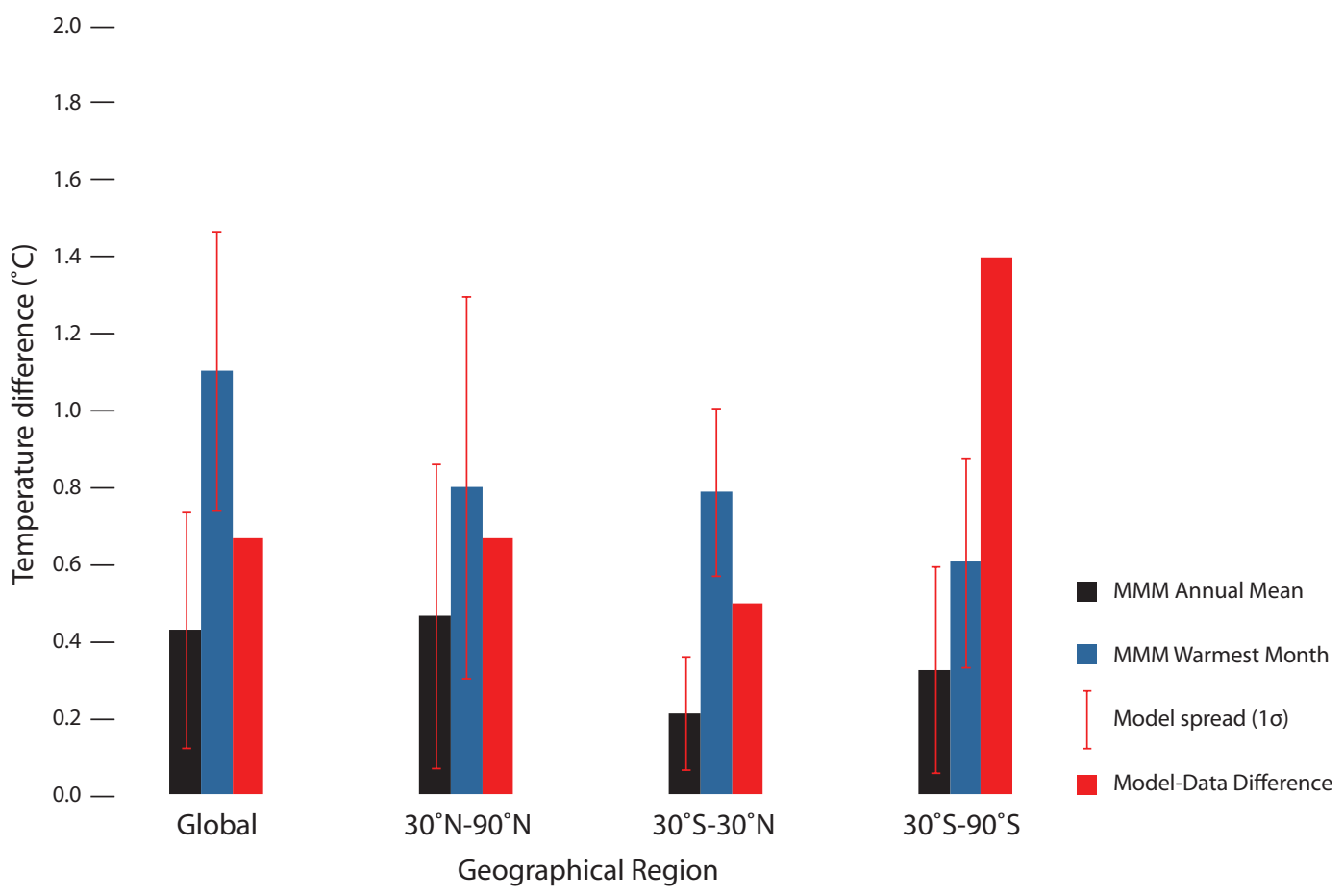

Figure 6. Comparison of calculated overestimation of the LIG thermal maximum and reported LIG model-data mismatch. The calculated MMM overestimation of annual mean (black) and warmest month temperatures (blue; ${ }^{\circ} \mathrm{C}$ ) during the LIG thermal maximum, including inter-model spread ( $1 \sigma$; red) compared with the model-data mismatch (red) reported by Otto-Bliesner et al. (2013). The calculated MMM overestimation is illustrated by the differences between the compilation-warmest-periods and the warmest-single-period methods. Values are given for four different geographical regions. The model-data mismatch is based on a combination of terrestrial and oceanic data, comparison at proxy locations only and on a CCSM3 simulation forced with $130 \mathrm{ka}$ forcings (see for details Otto-Bliesner et al., 2013).

Acknowledgements. This is Past4Future contribution no. 63. The research leading to these results has received funding from the European Union's Seventh Framework programme (FP7/2007-2013) under grant agreement no. 243908, "Past4Future. Climate change - Learning from the past climate" The authors gratefully acknowledge all groups for providing the simulated LIG temperature time series, in particular Sylvie Charbit, Matthias Gröger, Uta KrebsKanzow, Madlene Pfeiffer, Steven Phipps, Stefan Ritz, Emma Stone and Vidya Varma.

Edited by: D. Fleitmann

\section{References}

Bakker, P., Van Meerbeeck, C. J., and Renssen, H.: Sensitivity of the North Atlantic climate to Greenland Ice Sheet melting during the Last Interglacial, Clim. Past, 8, 995-1009, doi:10.5194/cp-8995-2012, 2012.

Bakker, P., Stone, E. J., Charbit, S., Gröger, M., Krebs-Kanzow, U., Ritz, S. P., Varma, V., Khon, V., Lunt, D. J., Mikolajewicz, U., Prange, M., Renssen, H., Schneider, B., and Schulz, M.: Last interglacial temperature evolution - a model inter-comparison, Clim. Past, 9, 605-619, doi:10.5194/cp-9-605-2013, 2013.

Bakker, P., Masson-Delmotte, V., Martrat, B., Charbit, S., Renssen, R., Gröger, M., Krebs-Kanzow, U., Lohmann, G., Lunt, D. J., Pfeiffer, M., Phipps, S. J., Prange, M., Ritz, S. P., Schulz,
M., Stenni, B., Stone, E. J., and Varma, V.: Temperature trends during the Present and Last interglacial periods - A multi-model-data comparison - Quat. Sci. Rev., 99, 224-243, doi:10.1016/j.quascirev.2014.06.031, 2014.

CAPE Last Interglacial Project Members: Last Interglacial Arctic warmth confirms polar amplification of climate change, Quat. Sci. Rev., 25, 1383-1400, 2006.

Clark, P. U. and Huybers, P.: Global change: Interglacial and future sea leve, Nature, 462, 856-857, 2009.

Collins, W. D., Bitz, C. M., Blackmon, M. L., Bonan, G. B., Bretherton, C. S., Carton, J. A., Chang, P., Doney, S. C., Hack, J. J., Henderson, T. B., Kiehl, J. T., Large, W. G., McKenna, D. S., Santer, B. D., and Smith, R. D., The Community Climate System Model Version 3 (CCSM3), J. Clim., 19, 2122-2143, 2006.

Edwards, N. R. and Marsh, R.: Uncertainties due to transportparameter sensitivity in an efficient 3-D ocean-climate model, Clim. Dyn., 24, 415-433, 2005.

Goosse, H., Brovkin, V., Fichefet, T., Haarsma, R. J., Huybrechts, P., Jongma, J. I., Mouchet, A., Selten, F. M., Barriat, P., Campin, J., Renssen, H., Roche, D. M., Timmermann, A. and Opsteegh, J. D., Description of the Earth system model of intermediate complexity LOVECLIM version 1.2, Geosci. Mod. Dev., 3, 309390, 2010.

Gordon, C., Cooper, C., Senior, C. A., Banks, H., Gregory, J. M., Johns, T. C., Mitchell, J. F. B. and Wood, R. A., The simulation 
of SST, sea ice extents and ocean heat transports in a version of the Hadley Centre coupled model without flux adjustments, Clim. Dyn., 16, 147-168, 2000.

Govin, A., Braconnot, P., Capron, E., Cortijo, E., Duplessy, J.-C., Jansen, E., Labeyrie, L., Landais, A., Marti, O., Michel, E., Mosquet, E., Risebrobakken, B., Swingedouw, D., and Waelbroeck, C.: Persistent influence of ice sheet melting on high northern latitude climate during the early Last Interglacial, Clim. Past, 8, 483-507, doi:10.5194/cp-8-483-2012, 2012.

Gregory, J. M., Dixon, K. W., Stouffer, R. J., Weaver, A. J., Driesschaert, E., Eby, M., Fichefet, T., Hasumi, H., Hu, A., Jungclaus, J. H., Kamenkovich, I. V., Levermann, A., Montoya, M., Murakami, S., Nawrath, S., Oka, A., Sokolov, A. P., and Thorpe, R. B.: A model intercomparison of changes in the Atlantic thermohaline circulation in response to increasing atmospheric $\mathrm{CO}_{2}$ concentration, Geophys. Res. Lett., 32, 1944-8007, 2005.

Gröger, M., Maier-Reimer, E., Mikolajewicz, U., Schurgers, G., Vizcaino, M. and Winguth, A., Vegetation-climate feedbacks in transient simulations over the last interglacial (128 000 - 113000 yr BP). In F. Sirocko, M. Claussen, M. S. Goni, and T. Litt (Eds.), The climate of past interglacials (pp. 563-572). Amsterdam: Elsevier, 2007.

Jones, P. D., Gregory, J., Thorpe, R., Cox, P., Murphy, J., Sexton, D. and Valdes, P., Systematic Optimisation and climate simulations of FAMOUS, a fast version of HadCM3, Clim. Dyn., 25, 189204, 2005.

Kaspar, F., Kühl, N., Cubasch, U., and Litt, T.: A model-data comparison of European temperatures in the Eemian interglacial, Geophys. Res. Lett., 32, L11703, doi:10.1029/2005GL022456, 2005

Kopp, R. E., Simons, F. J., Mitrovica, J. X., Maloof, A. C., and Oppenheimer, M.: Probabilistic assessment of sea level during the last interglacial stage, Nature, 462, 863-867, 2009.

Langebroek, P.M. and Nisancioglu, K. H.: Simulating last interglacial climate with NorESM: role of insolation and greenhouse gases in the timing of peak warmth, Clim. Past, 10, 1305-1318, doi:10.5194/cp-10-1305-2014, 2014.

Leduc, G., Schneider, R., Kim, J. H., and Lohmann, G.: Holocene and Eemian sea surface temperature trends as revealed by alkenone and $\mathrm{Mg} / \mathrm{Ca}$ paleothermometry, Quat. Sci. Rev., 29, 989-1004, 2010.

Lohmann, G., Pfeiffer, M., Laepple, T., Leduc, G., and Kim, J.-H.: A model-data comparison of the Holocene global sea surface temperature evolution, Clim. Past, 9, 1807-1839, doi:10.5194/cp-9-1807-2013, 2013.

Lunt, D. J., Abe-Ouchi, A., Bakker, P., Berger, A., Braconnot, P., Charbit, S., Fischer, N., Herold, N., Jungclaus, J. H., Khon, V. C., Krebs-Kanzow, U., Langebroek, P. M., Lohmann, G., Nisancioglu, K. H., Otto-Bliesner, B. L., Park, W., Pfeiffer, M., Phipps, S. J., Prange, M., Rachmayani, R., Renssen, H., Rosenbloom, N., Schneider, B., Stone, E. J., Takahashi, K., Wei, W., Yin, Q., and Zhang, Z. S.: A multi-model assessment of last interglacial temperatures, Clim. Past, 9, 699-717, doi:10.5194/cp-9-699-2013, 2013.

Marsland, S. J., Haak, H., Jungclaus, J. H., Latif, M. and Röske, F., The Max-Planck-Institute global ocean/sea ice model with orthogonal curvilinear coordinates, Ocean Mod., 5, 91-127, 2003.

Masson-Delmotte, V., Schulz, M., Abe-Ouchi, A., Beer, J., Ganopolski, A., Rouco, J. G., Jansen, E., Lambeck, K., Luter- bacher, J., Naish, T., Osborn, T., Otto-Bliesner, B., Quinn, T., Ramesh, R., Rojas, M., Shao, X., and Timmermann, A.: Information from Paleoclimate Archives, in: Climate Change 2013: The Physical Science Basis, Contribution of Working Group I to the Fifth Assessment Report of the Intergovernmental Panel on Climate Change, Cambridge University Press, Cambridge, United Kingdom and New York, NY, USA, 2013.

McKay, N. P., Overpeck, J. T., and Otto-Bliesner, B. L.: The role of ocean thermal expansion in Last Interglacial sea level rise, Geophys. Res. Lett., 38, L14605, doi:10.1029/2011GL048280, 2011.

Muller, S. A., Joos, F., Edwards, N. R., and Stocker, T. F., Water Mass Distribution and Ventilation Time Scales in a CostEfficient, Three-Dimensional Ocean Model, J. Clim., 19, 54795499, 2006.

Otto-Bliesner, B. L., Brady, E. C., Clauzet, G., Tomas, R., Levis, S., and Kothavala, Z.: Last Glacial Maximum and Holocene Climate in CCSM3, J. Climate, 19, 2526-2544, 2006.

Otto-Bliesner, B. L., Rosenbloom, N., Stone, E. J., McKay, N. P., Lunt, D. J., Brady, E. C., and Overpeck, J. T.: How warm was the last interglacial? New model - data comparisons, Philosophical Transactions of the Royal Society A: Mathematical, Phys. Engin. Sci., 371, 1-20, 2013.

Park, W., Keenlyside, N., Latif, M., Stroh, A., Redler, R., Roeckner, E. and Madec, G., Tropical Pacific Climate and Its Response to Global Warming in the Kiel Climate Model, J. Clim., 22, 71-92, 2009.

Petoukhov, V., Ganopolski, A., Brovkin, V., Claussen, M., Eliseev, A., Kubatzki, C. and Rahmstorf, S., CLIMBER-2: a climate system model of intermediate complexity. Part I: model description and performance for present climate, Clim. Dyn., 16, 1-17, 2000.

Phipps, S. J., Rotstayn, L. D., Gordon, H. B., Roberts, J. L., Hirst, A. C. and Budd, W. F., The CSIRO Mk3L climate system model version 1.0 - Part 1: Description and evaluation, Geosci. Mod. Dev., 4, 483-509, 2011.

Phipps, S. J., Rotstayn, L. D., Gordon, H. B., Roberts, J. L., Hirst, A. C. and Budd, W. F., The CSIRO Mk3L climate system model version 1.0 - Part 2: Response to external forcings, Geosci. Mod. Dev., 5, 649-682, 2012.

Renssen, H., Seppa, H., Heiri, O., Roche, D. M., Goosse, H., and Fichefet, T.: The spatial and temporal complexity of the Holocene thermal maximum, Nature Geosci., 2, 411-414, 2009.

Renssen, H., Seppa, H., Crosta, X., Goosse, H., and Roche, D. M.: Global characterization of the Holocene Thermal Maximum, Quat. Sci. Rev., 48, 7-19, 2012.

Ritz, S. P., Stocker, T. F. and Joos, F., A coupled dynamical oceanenergy balance atmosphere model for paleoclimate studies, J. Clim., 24, 349-375, 2011.

Ritz, S. P., Stocker, T. F. and Severinghaus, J. P., Noble gases as proxies of mean ocean temperature: sensitivity studies using a climate model of reduced complexity, Quat. Sci. Rev., 30, 3728 3741, 2011.

Roeckner, E., Bäuml, G., Bonaventura, L., Brokopf, R., Esch, M., Giorgetta, M., Hagemann, S., Kirchner, I., Kornblueh, L., Manzini, E., Rhodin, A., Schlese, U., Schulzweida, U. and Tompkins, A., The atmospheric general circulation model ECHAM5. PART I: Model description, Techical report, Max Planck Institute for Meteorology, MPI-Report, 2003. 
Schmidt, G. A., Jungclaus, J. H., Ammann, C. M., Bard, E., Braconnot, P., Crowley, T. J., Delaygue, G., Joos, F., Krivova, N. A., Muscheler, R., Otto-Bliesner, B. L., Pongratz, J., Shindell, D. T., Solanki, S. K., Steinhilber, F. and Vieira, L. E. A., Climate forcing reconstructions for use in PMIP simulations of the last millennium (v1.0), Geosci. Mod. Dev., 4, 33-45, 2012.

Schneider, B., Leduc, G., and Park, W.: Disentangling seasonal signals in Holocene climate trends by satellitemodel-proxy integration, Paleoceanography, 25, PA4217, doi:10.1029/2009PA001893, 2010.

Schurgers, G., Mikolajewicz, U., Gröger, M., Maier-Reimer, E., Vizcaíno, M. and Winguth, A., The effect of land surface changes on Eemian climate, Clim. Dyn., 29, 357-373, 2007.

Smith, R. and Gregory, J., The last glacial cycle: transient simulations with an AOGCM, Clim. Dyn., 38, 1545-1559, 2012.
Smith, R., The FAMOUS climate model (version XFXWB and XFHCC): description update to version XDBUA, Geosci. Mod. Dev., 5, 269-276, 2012.

Stone, E. J., Lunt, D. J., Annan, J. D., and Hargreaves, J. C.: Quantification of the Greenland ice sheet contribution to Last Interglacial sea level rise, Clim. Past, 9, 621-639, doi:10.5194/cp-9621-2013, 2013.

Turney, C. S. M. and Jones, R. T.: Does the Agulhas Current amplify global temperatures during super-interglacials?, J. Quat. Sci., 25, 839-843, 2010.

Waelbroeck, C., Frank, N., Jouzel, J., Parrenin, F., MassonDelmotte, V., and Genty, D.: Transferring radiometric dating of the last interglacial sea level high stand to marine and ice core records, Earth Planet. Sci. Lett., 265, 183-194, 2008. 